\title{
READING DOWN SECTION 44(i) OF THE AUSTRALIAN CONSTITUTION AS A METHOD OF AFFIRMING AUSTRALIAN CITIZENSHIP IN THE $21^{\text {ST }}$ CENTURY
}

\author{
Noa Bloch* and Kim Rubenstein ${ }^{\#}$
}

\begin{abstract}
Until 2017, the most recent disqualification of a member of the Australian Parliament under section 44(i) of the Australian Constitution ('Constitution') was Senator Heather Hill in 1998. Remarkably, since 2017, almost twenty years after Sue v Hill, ten parliamentarians have resigned or been disqualified, triggering a series of by-elections.

The catalyst for this flurry of activity occurred in July 2017, when Greens senator Scott Ludlam announced that at the time of his election, he was a citizen of New Zealand and was incapable of sitting in parliament under section 44(i). He was the first of ten senators and members of Parliament to be referred to the High Court of Australia in the cases of Re Canavan and later Re Gallagher on questions of eligibility under section 44(i). Eight of these parliamentarians were disqualified, sparking national debate around parliamentary representation and membership within the Australian community.

Since Re Canavan and Re Gallagher and indeed well before those cases, the section had and has continued to attract popular, journalistic, parliamentary and academic criticism. Consequently, there have been calls for a referendum on section 44(i) for a significant period of time. Whilst the authors support this call, this article reflects on the cases and develops a different interpretive approach to section 44(i) which if argued by the parties and adopted by the Court, would have rendered a referendum unnecessary. By drawing on the earlier section 41 of the Australian Constitution case of $R v$ Pearson; Ex parte Sipka and its majority
\end{abstract}

\footnotetext{
* Noa Bloch completed her honours law degree at Monash University in 2018 with her thesis: The Case for a Non-Originalist Construction of Section 44(i) of the Constitution (Honours Thesis, Monash University, 2018). Significant parts of this article draw from her thesis.

\# Kim Rubenstein is a Professor in the Law School, ANU College of Law, Australian National University.
} 
judgment, as well as drawing upon the minority judgment of Murphy $\mathrm{J}$ and a more recent feminist judgment written by Kim Rubenstein, one of the authors of this article, we argue that the principles of representative democracy and the sovereignty of the people could have acted as a frame to read down section 44(i). Had this approach been adopted, the Court could have effectively placed the decision around disqualification of parliamentarians around the issue of dual citizenship, back into the hands of the elected representatives.

Keywords: Australian Constitution; section 44 Australian Constitution; representative democracy; sovereignty of the people; Murphy $\mathrm{J}$; eligibility of MPs; nationality as parliamentary qualification; citizenship as parliamentary qualification; dual citizenship; $R$ v Pearson; Ex parte Sipka; feminist jurisprudence; feminist judgments; feminism and Australian Constitution.

\section{INTRODUCTION}

Until 2017, the most recent disqualification of a member of the Australian Parliament under section 44(i) of the Australian Constitution ('Constitution') was Senator Heather Hill in 1998. ${ }^{1}$ Remarkably, since 2017, almost twenty years after Sue $v$ Hill, ten parliamentarians have resigned or been disqualified, triggering a series of by-elections.

The catalyst for this flurry of activity occurred in July 2017, when Greens senator Scott Ludlam announced that at the time of his election, he was a citizen of New Zealand and was incapable of sitting in parliament under section 44(i). He was the first of ten senators and members of Parliament to be referred to the High Court of Australia in the cases of Re Canavan ${ }^{2}$ and later Re Gallagher ${ }^{3}$ on questions of eligibility under section 44(i). Eight of these parliamentarians were disqualified, sparking national debate around parliamentary representation and membership within the Australian community.

Section 44(i) is of paramount importance when thinking about representative democracy and citizenship in Australia. The section disqualifies from parliament any person who 'is under any acknowledgement of allegiance, obedience, or adherence to a foreign power, or is a subject or a citizen or entitled to the rights or privileges of a subject or a citizen of a foreign power. ${ }^{4}$ It therefore regulates who

\footnotetext{
1 Sue v Hill [1999] 199 CLR 462; 'Sue v Hill', ABC Fact Check, 'Fact file: The Dual Citizenship Crisis' (ABC News) <https://www.abc.net.au/news/2017-12-06/fact-file-thedual-citizenship-scandal/9147418> accessed 6 December 2017.

2 [2017] 91 ALJR 1209.

3 [2018] 92 ALJR 502.

4 Australian Constitution, section 44(i).
} 
can and cannot be elected to parliament and significantly impacts upon the nature of popular sovereignty and representative government. Whilst not every Australian will necessarily aspire to be a member of parliament, the capacity to run for public office can be understood as one of the 'highest' reflections of citizenship through representing fellow Australians in parliament and consequently, a reflection of a person's fullest form of membership within the Australian community. By articulating clear prerequisites to sitting in parliament, section 44(i) sets a threshold requirement for nomination to be considered for election and represents current restrictions on active citizenship in Australia - limiting dual citizens to voting as the fullest form of civic participation.

Since Re Canavan and Re Gallagher and indeed well before those cases, the section had and has continued to attract popular, ${ }^{5}$ journalistic, ${ }^{6}$ parliamentary ${ }^{7}$ and academic criticism. ${ }^{8}$ Consequently, there have been calls for a referendum on

5 See for example Arthur Marusevich, 'The War Against Section 44 and How we Can Defeat it' (Lawyers Weekly) <https://www.lawyersweekly.com.au/wig-chamber/23310-the-waragainst-section-44-and-how-we-can-defeat-it> accessed 28 May 2018; Rosie Lewis, 'By-election results strengthen calls to change section 44', (The Australian) <https://www. theaustralian.com.au/national-affairs/byelection-results-strengthen-calls-to-changesection-44/news-story/eaa5f35eedbe780e70186499c5cec0ff $>$ accessed 3 August 2018.

6 See for example Joe McIntyre, 'The Dual citizenship Saga Shows Our Constitution Must Be Changed, and Now' (The Conversation 17 November 2017) <https:// theconversation.com/the-dual-citizenship-saga-shows-our-constitution-must-be-changedand-now-87330>; Paul Karp, "Referendum "the only way" to solve Australia's citizenship crisis' (The Guardian) <https:/www.theguardian.com/australia-news/2018/may/08/ referendum-the-only-way-to-solve-australias-citizenship-crisis> accessed 8 May 2018.

7 Joint Committee on Foreign Affairs and Defence, Dual Nationality, Report (1976) 8; Department of Immigration and Ethnic Affairs, National Consultation on Multiculturalism and Citizenship, Report (1982) 28; see Australia, Parliament, Joint Standing Committee on Migration, Australians All: Enhancing Australian Citizenship (1994) ch 6; see Australian Citizenship Council, Australian Citizenship for a New Century (February 2000) 60-66; Australia, Parliament, Standing Committee on Legal and Constitutional Affairs, Aspects of Section 44 of the Australian Constitution (July 1997).

8 See for example Kim Rubenstein, From this time forward ... I pledge my loyalty to Australia: loyalty, citizenship and constitutional law in Australia, ANU College of Law <https://papers.ssrn.com/sol3/papers.cfm?abstract_id=1130626> accessed 8 May 2018; Andrew Brown, 'Referendum to Change Section 44 Should be Held at Election, Law Expert Says' (The Sydney Morning Herald) <https://www.smh.com.au/national/act/ referendum-to-change-section-44-should-be-held-at-election-law-expert-says-20180307h0x5oe.html> accessed 10 March 2018. 
section 44(i) for a significant period of time. ${ }^{9}$ Whilst the authors support this call, this article reflects on the cases and develops a different interpretive approach to section 44(i) which, if argued by the parties and adopted by the Court, would have rendered a referendum unnecessary. ${ }^{10}$ By drawing on the earlier section 41 of the Australian Constitution case of $R v$ Pearson; Ex parte Sipka ${ }^{11}$ and its majority judgment, as well as drawing upon the minority judgment of Murphy $\mathrm{J}$ and a more recent feminist judgment written by Kim Rubenstein, one of the authors of this article, we argue that the principles of representative democracy and the sovereignty of the people could have acted as a frame to read down section 44(i). Had this approach been adopted, the Court could have effectively placed the decision around disqualification of parliamentarians around the issue of dual citizenship, back into the hands of the elected representatives.

\section{SECTION 44(i) AND CITIZENSHIP IN AUSTRALIA}

Australian citizenship is not defined in the Constitution. Section 44(i) is the only part of the Constitution to refer to the word citizen, but not Australian citizens, rather citizens of a foreign power. Delegate John Quick argued to include a definition of citizenship in the Constitution to empower the Commonwealth to regulate citizenship and membership within the Australian community. ${ }^{12}$

9 See for example Matthew Doran, 'Will We Actually Vote on Changing the Constitution After the Dual Citizenship Fiasco?' (ABC News) <http://www.abc.net.au/news/2018-0517/section-44-committee-recommendations-after-citizenship-fiasco/9770606> accessed 17 May 2018.

10 The authors resist the argument that only a referendum could have cured the constitutional crisis caused by section 44(i) for two reasons. First, the constitutional requirement that a referendum be supported by a majority of states, in addition to a majority of voters, adds a Federal hurdle effectively giving some states' voters more power over what is otherwise a national issue and thereby compromises the principle of representative democracy. Second, only eight out of forty-four referendums have been successful since Federation. This highlights the difficulty of the process which should not be the preferred option for what is otherwise an interpretive 'problem' posed by section 44(i) and undermines the constitutionally entrenched values of representative democracy and popular sovereignty. This article, however, highlights what could have been a different approach, although the decisions of Re Canavan and Re Gallagher have minimised this approach being adopted during this Court's term.

11 [1983] 152 CLR 254.

12 Kim Rubenstein, 'Citizenship and the Constitutional Convention Debates: A Mere Legal Inference’ (1997) 25(2) FLR 295. 
However, despite citizenship being discussed multiple times during the Convention Debates, Quick's suggestion was rejected. ${ }^{13}$

As Rubenstein writes, although there were many reasons for Australian citizenship not to be included in the Constitution, ${ }^{14}$ there was agreement around section 44(i) which was intended to safeguard against treason by "prevent[ing] persons with foreign loyalties or obligations from being members of the Australian Parliament'. ${ }^{15}$ As Rubenstein explains:

The delegates were therefore content to disqualify people whose allegiance was to a foreign power because '[p]ersons who have taken the oath of allegiance to a foreign power are not to be classed in the same category as citizens of the country for the purpose of joining in legislation'. This led to an interjection 'And not to be trusted!'16

The framers' presumption that dual nationality was 'undesirable, incompatible with individual loyalties ${ }^{17}$ reflects the international norms of the $18^{\text {th }}$ and $19^{\text {th }}$ centuries, "characterised by aggressive nationalism and territorial competition"18 and the unresolved question of whether sole allegiance is central to Australian citizenship. ${ }^{19}$

But what does allegiance mean in the $21^{\text {st }}$ century compared to the $18^{\text {th }}$ and $19^{\text {th }}$ centuries? When the ten parliamentarians were recently referred to the High Court, the Court was not encouraged by the parties to look at the question of the changed meaning of allegiance in Australia. Rather, the submissions led to the High Court of Australia determining that section 44(i) captures two categories of dual nationals. ${ }^{20}$ It includes people who are:

1. 'under any acknowledgement of allegiance, obedience, or adherence to a foreign power' ${ }^{21}$ or

13 Ibid.

14 Ibid; Patrick Emerton, 'Political Freedoms and Entitlements in the Australian Constitution: An Example of Referential Intentions Yielding Unintended Legal Consequences' (2010) 38(2) FLR 169, 169.

15 Sykes v Cleary [1992] 176 CLR 77, 127.

16 Rubenstein (n 12) 302.

17 Rubenstein (n 8) 24.

18 Ibid. See also Peter Spiro, 'Dual Nationality and the Meaning of Citizenship' (1997) 46(4) ELJ 1411.

19 Rubenstein (n 12).

${ }^{20}$ Re Canavan [2017] 91 ALJR 1209.

21 Australian Constitution section 44(i). 
2. a 'subject or a citizen or entitled to the rights or privileges of a subject or a citizen of a foreign power'. ${ }^{22}$

The first limb looks to the 'conduct of the person concerned'. ${ }^{23}$ The second limb concerns the duties attached to one's foreign citizenship (as determined by the foreign power), irrespective of the individual's feelings of loyalty and allegiance. ${ }^{24}$ This distinction was key to Brennan J's judgment in Sykes and was adopted by the Court in Re Canavan.

Justice Brennan's approach in Sykes was supported by the majority. In contrast, Deane J dissented in Sykes on the grounds that as the former 'involves an element of acceptance or at least acquiescence on the part of the relevant person', ${ }^{25}$ the latter should also be constructed to impliedly contain a mental element; to only capture 'cases where the relevant status, rights or privileges have been sought, accepted, asserted or acquiesced in by the person concerned'. ${ }^{26}$ Whilst Deane J's approach underpinned some of the applicants' submissions in Re Canavan these were unanimously rejected in favour of the majority decision in Sykes.

\section{Re Canavan and Re Gallagher}

In Re Canavan, three submissions were put to the Court on behalf of those seeking to resist disqualification. First, representing Senators Canavan, Roberts and Xenophon, the Attorney General argued that section 44(i) was 'said to import a requirement that the person know or be wilfully blind about his or her foreign citizenship ${ }^{27}$ and should only be enlivened if foreign citizenship was voluntarily obtained or retained. Counsel for Joyce and Nash argued that the foreign citizenship must be actively chosen or maintained, as 'a person cannot make a choice to retain or renounce any foreign citizenship if he or she has no knowledge of that citizenship. ${ }^{28}$ Additionally, counsel for Ludlam and Waters submitted that

22 Ibid.

23 Re Canavan [2017] 91 ALJR 1210.

${ }^{24}$ Martin Clark, 'Re Canavan; Re Joyce; Re Ludlam; Re Nash; Re Roberts; Re Waters; Re Xenophon' (Opinions on High) <https://blogs.unimelb.edu.au/opinionsonhigh/2017/ 12/06/re-canavan-et-al-case-page/> accessed 6 December 2017.

25 Sykes [1992] 176 CLR 77, 127.

26 Ibid.

27 Re Canavan [2017] 91 ALJR 1214. In summarising the case for this article, the authors benefitted from the excellent summary in Clark (n 24) <http://blogs.unimelb.edu.au/ opinionsonhigh/2017/12/06/re-canavan-et-al-case-page/> accessed 20 November 2018.

28 Ibid. 
section 44(i) should only capture a candidate or member that is 'put on notice'; ${ }^{29}$ the candidate or member must have 'had knowledge of the facts that, in the mind of a reasonable person taking a properly diligent approach to compliance with the Constitution, ought to call into question the belief that he or she is not a subject or citizen of a foreign power and prompt proper inquiries. ${ }^{30}$ All three submissions argued for a narrow, non-originalist construction of the section which imports a knowledge requirement.

In reaching its decision to reject these constructions of section 44(i), the Court was informed by several factors, placed before the Court in the arguments of Tony Windsor, ${ }^{31}$ challenging $\mathrm{Mr}$ Joyce's membership of parliament and a Courtappointed Amicus Curiae ${ }^{32}$ to assist the Court in hearing arguments against the applicants.

29 Ibid.

30 Ibid.

31 Some of the arguments made by counsel for Mr Windsor were reflected in the majority's decision. First, Counsel described the Attorney-General as attempting to 'resurrect' Deane J's dissent in Sykes, effectively calling on the Court to reopen a matter that had already been settled in subsequent cases, such as the High Court case of Sue v Hill, and referred to by the court in at least eleven other matters. Furthermore, Counsel outlined six similarities between Mr Joyce's and Mr Kardamitsis's circumstances, arguing that the former should therefore also be disqualified. This was reflected in Re Canavan when the Court's strictly applied section 44(i) in accordance with the majority in Sykes and disqualified Mr Joyce. Second, the Court's outright rejection of imputing a knowledge requirement is consistent with Counsel's submission that the purpose of section 44(i) was to only disqualify people on the basis of objective, ascertainable fact, and not subjective vagaries. This is necessary to ensure certainty of the electoral process to ensure candidates know whether they can run for election and electors know who they are able to vote for. Counsel grounded this submission in the drafting history of the text. This was also reflected in the majority's reasoning which drew heavily on the different drafts of section 44(i) considered by the framers during the Constitutional Debates. Third, Counsel submitted that disqualification under section 44(i) is based on the laws of the foreign power in question. This is consistent with the Court's finding in $R e$ Canavan. See Mr Antony Harold Curties Windsor, 'In the matter of questions referred to the Court of Disputed Returns pursuant to section 376 of the Commonwealth Electoral Act 1918 (Cth) concerning the Hon. Barnaby Joyce MPs submission in Re Canavan, No. C15 of 2017, [11], [13], [15], [17], [37], [39] <http://www.hcourt.gov.au/assets/cases/03-Canberra/c11-2017/ Joyce_WindsorSubs.pdf $>$ accessed 3 October 2017.

32 Amici Curiae, 'Re Senator the Hon Matthew Canavan, Re Senator the Hon Fiona Nash, Re Senator Nick Xenophon, References under section 376 of the Commonwealth Electoral Act 1918 (Cth)' Submission in Re Cananvan, No. C11 of 2017, No. C17 of 2017, No. C18 of $2017<$ http://www.hcourt.gov.au/assets/cases/03-Canberra/c11-2017/Canavan_ KennettSubs.pdf $>$ accessed 20 November 2018. 
First, the Court considered the drafting history as not supportive of a narrow, non-originalist construction of the section. Between 1891 and 1899, different drafts of section 44(i) were considered by the constitutional framers. However, as the clauses 'remained in substantially identical form', ${ }^{33}$ the differences between the different drafts could not 'be attributed to any articulated difference in the mischief', ${ }^{34}$ namely that disqualification was intended to focus on the specific acts of the parliamentarian in becoming a subject, or becoming entitled to the rights of a subject or citizen of a foreign power.

Secondly, the Court held that determination of a parliamentarian's status as a subject or citizen of a foreign power exclusively depends on the citizenship laws of the foreign power in question. Importantly, the Court outlined two notable exceptions to this rule - where the disqualification would undermine the constitutional principles of representative and responsible government ${ }^{35}$ and where a parliamentarian has made a reasonable effort to comply with the section.

A parliamentarian will have made a reasonable effort to comply if they take reasonable steps to divest themselves of the rights or privileges of a citizen of a foreign power. This will depend on the "situation of the individual, the requirements of the foreign law and the extent of the connexion between the individual and the foreign State'. ${ }^{36}$

The Court then expanded on what this means in Re Gallagher. The constitutional imperative of divestment under section 44(i) will be satisfied if the 'foreign law operates irremediably to prevent an Australian citizen from participation, ${ }^{37}$ and the citizen has taken all steps reasonably required under the foreign law that 'are within his or her power to free himself or herself of the foreign nationality'. ${ }^{38}$ A foreign law is considered to irremediably prevent divestment if it presents an 'insurmountable obstacle' ${ }^{39}$ such as requiring a dual citizen to explicitly renounce their citizenship in the territory of the foreign power and put themselves at risk.

\footnotetext{
33 Re Canavan [2017] 91 ALJR 1210, 1217.

34 Ibid.

35 In separate judgments in Sykes, Brennan and Deane JJ argued that an originalist construction of section 44(i) could lead to consequences unintended by the framers. If section 44(i) is subject to foreign citizenship laws, a foreign power could disqualify all parliamentarians by conferring citizenship on them, thereby triggering the section and stimulating a constitutional crisis. See Sykes [1992] 176 CLR 77, 113, 126-27.

36 Ibid 108.

37 Re Gallagher [2018] 92 ALJR 502, 508.

38 Ibid.

39 Ibid.
} 
Finally, the Court held that recognising a knowledge requirement in section 44(i) would pose 'conceptual difficulties' ${ }^{40}$ It would be difficult to ascertain the level of knowledge a parliamentarian would require to enliven section 44(i), as this could range from the "faintest inkling'41 through to "absolute certainty... In turn, application of section 44(i) would turn on the "unstable distinction between overt voluntary acts and conscious omissions ${ }^{243}$ and would require the impossible task of inquiring into the parliamentarian's state of mind at the time of nomination.

Whilst these arguments show consistency regarding the Court's approach from Sykes onwards, we argue there could have been a different approach placed before the Court to interpreting section 44(i). By considering the democratic context of section 44(i) within the Constitution and the democratic constituency that Australia has evolved to include, we argue that the Court could have been encouraged to look at another provision, section 41 of the Constitution, to assist in reading down the section, and to reconsider the meaning of allegiance in the $21^{\text {st }}$ century.

Section 41 deals with a significant aspect of representative democracy - the 'right to vote'. It states:

No adult person who has or acquires a right to vote at elections for the more numerous House of the Parliament of a State shall, while the right continues, be prevented by any law of the Commonwealth from voting at elections for either House of the Parliament of the Commonwealth. ${ }^{44}$

This section is another example of active citizenship provided for in the Constitution. Indeed, one needs to be eligible to vote before one can be eligible to be represented in parliament. Since section 41 and 44(i) both provide for active civic engagement - through voting and through being a representative of the voters arguments raised in relation to construction of the former could have informed construction of the latter and could have been argued by the relevant parties resisting disqualification in Re Canavan.

\footnotetext{
40 Re Canavan [2017] 91 ALJR 1221.

41 Ibid.

42 Ibid.

43 Ibid.

44 Australian Constitution section 41.
} 


\section{MAJORITY DECISION IN SIPKA}

On 3 February 1983, then Prime Minister Malcolm Fraser called a snap election and closed the electoral rolls early, preventing thousands of eligible voters from enrolling to vote..$^{45}$ This was used as a test case by the applicants to explore the parameters of section 41. The applicants argued that by closing the rolls early, eligible voters under the state franchise of New South Wales ('NSW') were deprived of their right to vote, in contravention of section 41 .

The scope of section 41 was explored by both the judgments of the majority in Sipka, as well as the minority and aspects later identified as relevant to the minority decision. This article considers the two judgments separately and outlines parallel arguments that could have been made by the parties in relation to section 44(i).

All judges in Sipka referred to historical considerations to deliver interpretations of section 41.

The majority ${ }^{46}$ read down section 41 as serving only a temporary purpose: to preserve 'only those rights which were in existence before the passing of the Commonwealth Franchise Act 1902' ${ }^{47}$ Limiting section 41 preserved the uniform commonwealth franchise 'over whatever advantage might have accrued to individual voters had the section been given a continuing operation'. ${ }^{48}$

This decision is still considered controversial as it rendered section 41 obsolete. ${ }^{49}$ However, as the decision is yet to be reversed, it serves as a practical illustration of a court referring to historical considerations when engaging in constitutional construction ${ }^{50}$ and where necessary, reading down a provision

45 See the description of the context of the case coming before the High Court in Elisa Arcioni and Kim Rubenstein, ' $R v$ Pearson; Ex Parte Sipka: Feminism and the Franchise' in Heather Douglas and others (eds), Australian Feminist Judgments: Writing and Rewriting Law (Hart Publishing 2014) 55.

46 Gibbs CJ, Mason and Wilson JJ delivered one joint judgment; and Brennan, Dawson and Deane JJ delivered a second joint judgment.

47 Sipka [1983] 152 CLR 254, 264.

48 Cheryl Saunders, The Constitution of Australia (Hart Publishing 2011) 142.

49 For a detailed critical analysis, see Anne Twomey, 'The Federal Constitutional Right to Vote in Australia' (2000) 28(1) FLR 125; Peter Hanks, Constitutional Law in Australia (Butterworths $2^{\text {nd }}$ ed 1996); Adrian Brooks, 'A Paragon of Democratic Virtues? The Development of the Commonwealth Franchise' (1993) 12(2) University of Tasmania Law Review 208.

50 Jonathan Crowe and Peta Stephenson agree with Murphy J and dispute whether the history of section 41 supports the majority's finding that the section was intended as transitional. However, since they consider Murphy J's judgment persuasive and do not object to his methodology of permitting history to inform constitutional construction, their argument does not contradict the insight drawn from Sipka by this article. See Jonathan Crowe and Peta Stephenson, 'An Express Constitutional Right to Vote? The Case for Reviving Section 41' (2014) 36(2) Sydney Law Review 205. 


\section{THE DENNING LAW JOURNAL}

where the social context of the section has changed so significantly to render the provision obsolete.

The most methodologically significant consideration of the majority was the drafting history of section $41 .^{51}$ They held it revealed the 'apprehended mischief's2 as protecting the women of South Australia until their rights to vote were enshrined in the federal franchise.

After women were granted the right to vote in South Australia in 1895 and Western Australia in 1899, South Australia threatened to boycott Federation ${ }^{53}$ unless a constitutional franchise included women. ${ }^{54}$ The delegates from other colonies opposed this. To ensure unity and defer discussions to a future parliament, the delegates agreed on section 41 as a compromise. ${ }^{55}$ It guaranteed the right to vote to anyone who had the right at the state level at the time of Federation, thereby including the women of South Australia. ${ }^{56}$ Informed by this background history, the majority recognised section 41 as transitional and as of 1902, when the Commonwealth Parliament had already legislated the universal franchise, ${ }^{57}$ serving no further purpose.

Importantly, this decision serves as precedent for reading down constitutional text to honour the constitutional history of the text in question. Where the history suggests that the framers drafted the text to meet a specific purpose, and that purpose no longer exists, the text in question can be rendered obsolete.

This approach is relevant to section 44(i). Developments in Australian citizenship legislation reveal a change in the meaning of membership within the

51 For the sake of completeness, the majority outlined two other reasons which are not directly relevant to this article. First, sections 8 and 30 of the Constitution confer the federal franchise on state electors 'until the Parliament otherwise provides'. Thus, interpreting the Constitution holistically, section 41 was only intended to protect a statevoter's right to vote until the national franchise was established by Parliament in 1902 . Second, if section 41 was to establish a constitutional federal franchise (as argued by the applicants), the uniform franchise could be amended by the laws of any state. This would render redundant section 128 of the Constitution which permits constitutional amendments only by referendum and would destroy the Parliament's power to legislate regarding the uniform franchise. See Sipka [1983] 152 CLR 254, 277-79.

52 Sipka [1983] 152 CLR 254, 262.

53 This article adopts the capitalisation of the word 'Federation' in this section to be consistent with the Court's judgment in Sipka.

54 Arcioni and Rubenstein (n 45).

55 Ibid.

56 Sipka [1983] 152 CLR 254.

57 Franchise Act 1902 (Cth) ('Franchise Act'). Note the Franchise Act did not enfranchise indigenous women, as discussed also in Arcioni and Rubenstein (n 45). 
Australian citizenship community. Since 1901, when section 44(i) was drafted, Australian citizenship law has grown increasingly tolerant of multiculturalism and dual nationality. Most significantly, dual citizenship was fully embraced legislatively in 2002 with the repeal of then section 17 of the Australian Citizenship $\mathrm{Act}^{58}$ that had earlier mandated loss of Australian citizenship on the taking up of a new citizenship. ${ }^{59}$ We argue that the purpose for which section 44(i) was drafted no longer exists and similar to section 41 , could have been argued to be redundant.

Until 1949, a 'British subject' was the formal status of a full member of the Australian community. After the Australian Citizenship Act ${ }^{60}$ came into effect, citizenship encompassed both Australian citizens and British subjects. ${ }^{61}$ This remained the case until 1987 when full membership of the Australian community was conferred on Australian citizens alone. ${ }^{62}$ Since between 1949 and 1987, the term 'Australian' applied to both Australian citizens and British subjects; this suggests that 'loyalty and allegiance in Australia ... [could] cope with varying forms of identity and membership'. ${ }^{63}$

Furthermore, for many decades there was debate about whether section 17 of the Citizenship Act, which automatically stripped an Australian of their citizenship if they took up citizenship of another country, should be repealed. Already at the 1976 Joint Committee on Foreign Affairs and Defence and the 1982 national consultations regarding multiculturalism and citizenship, section 17 was critically reviewed ${ }^{64}$ for three reasons. First, it was inconsistent as it only stripped some Australians of their citizenship, depending on the order in which the citizenships were obtained ${ }^{65}$ For example, if a Swiss citizen moved to Australia and satisfied the requirements to obtain Australian citizenship, section 17 would not require

582007 (Cth) ('Citizenship Act').

59 For a fuller explanation of the story of dual citizenship in Australia, see Kim Rubenstein and Jacqueline Field, 'Australian Citizenship Act 2007 (Cth)' in Australian Citizenship Law (Thomson Reuters, $2^{\text {nd }}$ edn, 2017) 91.

601948 (Cth).

61 Rubenstein (n 8).

62 Ibid. After 1987, British subjects lost their privileged status under Australian citizenship law unless they obtained Australian citizenship. However, British subjects listed on the Commonwealth electoral roll were entitled to remain under section 93(1) of the Commonwealth Electoral Act 1918 (Cth). See Rubenstein and Field (n 59).

63 Kim Rubenstein, 'Loyalty and Membership: Globalization and its Impact on Citizenship, Multiculturalism, and the Australian Community' in Geoffrey Braham Levey (ed), Political Theory and Australian Multiculturalism (Berghahn Books 2008) 171, 176.

64 Rubenstein (n 8).

65 Ibid. 
them to give up their Swiss citizenship, ${ }^{66}$ whereas an Australian who moved to Switzerland and obtained Swiss citizenship would lose their Australian citizenship automatically. ${ }^{67}$ Second, in the increasingly globalised world, it was deemed 'anachronistic that one section of the Australian population should be disadvantaged by a prohibition on accessing more than one citizenship. ${ }^{68}$ Finally, the Australian Citizenship Council suggested that a connection to an additional country does not detract from one's connection to their birth country. As explained by the Council:

The law and practice of most countries with which Australia likes to compare itself permits citizens of those countries to obtain another citizenship without losing their original citizenship ... These countries simply recognize that they have an internationally mobile population and that they can retain connection with this population even if another citizenship is acquired. ${ }^{69}$

Castan even considered the section unconstitutional. Excluding dual nationals from the 'people of the Commonwealth', even if they do not intend to cease membership within the Australian citizenship community, undermines the intended meaning of that constitutional term. ${ }^{70}$

By 4 April 2002, the section was repealed. This repeal meant that from that date, the concept of not allowing and not 'trusting' within Australia, people with a 'foreign' citizenship, was no longer relevant to any aspect of Australian citizenship legislation. All Australians could be dual citizens, no matter which way they became a dual citizen. In our view, this was a significant legislative step in relation to the interpretation of section 44(i).

Indeed, this legislative history reveals two further parallels between sections 41 and 44(i) which justify applying the majority's constitutional methodology in Sipka to section 44(i). First, it is uncontroversial that sections 44 and 45 of the Constitution were intended to disqualify from parliament any person whose loyalty and judgment could be questioned because of other obligations or responsibilities they may have. ${ }^{71}$ In fact, this was clarified during the Convention Debates when the framers interrupted the Debates to refer to dual citizens as

\footnotetext{
66 Ibid.

67 Ibid.

68 Rubenstein (n 8) 31.

69 Rubenstein and Field (n 59) 272, quoting Australian Citizenship Council, above (n 7) 65.

70 Ibid.

71 n 15 and the accompanying text.
} 
untrustworthy. ${ }^{72}$ Therefore, just as section 41 was intended to protect female voting rights federally, section 44(i) was intended to protect the Parliament from people considered disloyal or untrustworthy.

Yet, Australian citizenship law now accepts and embraces dual nationality. This directly contradicts the current, strict construction of section 44(i) and suggests that the apprehended purpose of the section is now redundant.

Second, reading down section 44(i) responds to a legislative shift, similar to section 41 . In deciding to read down section 41 , the majority was influenced by the Franchise Act. Once parliament enfranchised women in 1902 as part of the universal franchise, section 41 was no longer necessary and could be read down. Similarly, the repeal of section 17 of the Citizenship Act has signified a profound legislative shift in the understanding of citizenship and membership in Australia, allowing and affirming dual citizenship, such that section 44(i) should be read down.

Moreover, the Court's decision in Sue v Hill further justifies applying the constitutional methodology of reading the text down. In Sue v Hill, the Court considered whether Heather Hill, a dual citizen of the United Kingdom ('UK') and Australia, was disqualified from sitting as a senator under section 44(i). Although at Federation all Australians were considered British subjects, the Court disqualified Hill on the grounds the term 'foreign power' in section 44(i) had evolved to include the UK. The Court held 'some words and phrases are capable of applying to different persons or things at different times, ${ }^{73}$ As explained in Roach $v$ Electoral Commissioner: ${ }^{74}$

In 1901, the words 'foreign power' in s[ection] 44(i) did not include the United Kingdom, yet in Sue v Hill this Court held that, by reason of changes in Australia's relations with the United Kingdom and in national and international circumstances over the intervening period, they had come to include the United Kingdom. The meaning of the words 'foreign power' did not change, but the facts relevant to the identification of the United Kingdom as being included in or excluded from that meaning had changed. ${ }^{75}$

In finding the two countries to be separate legal entities, the Court reflected on historical changes in the legal and political relationship between the UK and Australia. The passage of the Australia Act $^{76}$ was evidence of this. Australian courts were not 'bound to recognise and give effect ... [to] the institutions of

72 n 16.

73 Sue v Hill [1999] 199 CLR 462, 526 [167].

74 [2007] 233 CLR 162.

75 Ibid 173-74, [6].

761986 (Cth) ('Australia Act'). 
government of the United Kingdom', ${ }^{77}$ the UK could no longer pass legislation to bind Australia ${ }^{78}$ nor could the Privy Council hear any appeals from the Court. ${ }^{79}$

Therefore, when section 44(i) was drafted, it was inconceivable that the framers intended the term 'foreign power' to capture the UK. Indeed, during the Convention Debates it was considered 'simply monstrous that those who were born in England should in any way be subjected to the slightest disabilities' ${ }^{80}$ However, at least by 1999 , when Sue v Hill was decided, Australian citizenship excluded British subjects.

This was consistent with the decision in Nolan $v$ Minister for Immigration and Ethnic Affairs ${ }^{81}$ when the Court considered the meaning of the word 'alien' in section 12 of the Migration Act 1958 (Cth). In Nolan, the Court conceded that the framers could not have conceived of British subjects as aliens. However, as Australia had gained legislative and cultural independence from the UK throughout the $20^{\text {th }}$ century, Australian citizenship had developed to be independent of British citizenship.

Therefore, developments in Australian citizenship law suggest that membership within the Australian citizenship community has changed profoundly since 1901 . Moreover, both Sue v Hill and Nolan prove that the frame of reference of section 44(i) - the term 'foreign power' - has died. Hence, similar to section 41, the intended mischief of section 44(i) is no longer operative and the section could have been read down.

\section{MINORITY DECISION IN SIPKA}

Justice Murphy's dissent in Sipka interpreted section 41 broadly and critically, was also informed by the drafting history and social context of the section. ${ }^{82}$ Justice Murphy noted that when the precursor to section 41 was discussed at the

\footnotetext{
77 Sue v Hill [1999] 199 CLR 462, 490 [59].

78 Ibid.

79 Ibid.

80 Record of the Debates of the Convention (Melb 1989) vol V, 1760.

81 [1988] 165 CLR 178.
}

82 Although not directly relevant to this article, it should be noted that Murphy $\mathrm{J}$ also considered policy ramifications in his decision. If section 41 is not broadly applied to guarantee the right to vote, future parliaments could target certain classes of citizens by excluding them from the federal franchise. Until its removal in 1962, section 4 of the Franchise Act disqualified Indigenous Australians from the Federal franchise, even though they could vote in state elections in NSW, Victoria and Tasmania. If section 41 was not intended to be interpreted broadly, the voting rights of Indigenous Australians in these states would have remained unprotected until 1962. This could have set a dangerous precedent, allowing future parliaments to deprive different classes of citizens of their Commonwealth right to vote. See Sipka [1983] 152 CLR 254, 270-71. 
Convention Debates, Sir Edmund Barton feared the section would empower state legislatures to extend the franchise by enfranchising people at the state level. ${ }^{83}$ Responding to these fears, Sir Isaac Isaacs proposed an altered version of section $41 .{ }^{84}$ The 1901 version of section 41 omitted Isaacs's alterations, suggesting that Barton's fears would still stand and that a broader reading of section 41, as argued by the applicants, still applies. ${ }^{85}$

However, unlike the majority, Murphy $\mathrm{J}$ extended his historical analysis beyond the drafting history, to the history of the universal federal franchise in Australia. Justice Murphy reasoned that since Indigenous Australians were still excluded from the federal franchise until 1962, section 41 had to be interpreted broadly to guarantee the voting rights of the Indigenous population already exercising this right at the state level. ${ }^{86}$ Therefore, although Murphy J's construction of section 41 accounted for its drafting history, he diverged from the majority methodologically by analysing the broader history of the federal franchise. ${ }^{87}$

Rubenstein - one of the current authors - offered an alternate feminist judgment of Sipka developed as part of a larger Feminist Judgments Project. ${ }^{88}$ Rubenstein interprets section 41 broadly as guaranteeing a fair voting system in Australia and preserving representative government. This is driven by an in-depth analysis of the personalities and social movements that impacted the drafting of section 41 and like Murphy J, goes beyond the discussions of the Convention

$\begin{array}{ll}83 & \text { Ibid. } \\ 84 & \text { Ibid. } \\ 85 & \text { Ibid. } \\ 86 & \text { Ibid. }\end{array}$

87 Although not directly relevant to this article, Murphy $\mathbf{J}$ outlined three additional reasons. First, the plain words of the section, which guarantee every adult voter in state elections the right to vote in federal elections, reveal the section's purpose and favour a broad construction. Secondly, by purposefully omitting the limiting phrase used in other parts of the Constitution, 'until the Parliament otherwise provides,' the framers implied that section 41's application should not be limited as transitional. See for example Australian Constitution section 30. Finally, although merely persuasive, Murphy J considered it noteworthy that Parliament has continued to refer to section 41 as guaranteeing the right to vote in legislation. See for example Electoral Act 1918 (Cth) section 39. See Sipka (1983) 152 CLR 254, 268-69, 273-74.

88 The Australian Feminist Judgments Project brings together feminist lawyers, academics and activists to write alternative feminist judgments to a series of cases. The Project seeks to explore the opportunities and limitations of applying a feminist approach to legal decision-making in Australia. See TC Beirne School of Law, Australian Feminist Judgments Project, the University of Queensland <https://law.uq.edu.au/the-australianfeminist-judgments-project $>$ accessed 20 November 2018. 
Debates. Rubenstein focuses on the suffrage movement of South Australia and Western Australia and their work in bringing section 41 into fruition. Led by Catherine Helen Spence, these movements 'impress[ed] upon their representatives that they would not vote in favour of Federation if their vote was not protected'. ${ }^{89}$ They lobbied to secure section 41 as a guarantee of the fairest possible voting system in Australia. According to Rubenstein, this history highlights the mischief of section 41 as establishing a constitutional guarantee of a fair and democratic right to vote in Australia. Thus, any attempts to limit that guarantee by closing the electoral rolls early is a direct contravention of section 41.

Methodologically, this approach is more like Murphy J's dissent than the majority's judgment. Instead of relying purely on the Convention Debates and drafting history, Rubenstein's judgment is informed by the aspirations for section 41 of individuals, like Spence, who influenced the drafting of the section but were not themselves framers.

This constitutional methodology could be applied to section 44(i) in two ways.

First, just as Murphy $\mathrm{J}$ and Rubenstein's understanding of section 41 was informed by the broader history of the Australian franchise, the Court's application of section 44(i) could account for cultural developments in Australia, specifically in relation to immigration. Australia's immigration history reveals the nation's transition from a people fearful of difference to accepting of multiculturalism and dual citizenship. ${ }^{90}$

The attempt to root out dual nationality in Australia was fuelled by the widely held belief that nation-states must be organised along racially homogenous lines as 'any loosening of racial restrictions was seen as inviting inevitable civic and political discord'. ${ }^{91}$ This was best manifest in the White Australia policy which gave legislative credence to Australians' belief that '[b]oth the indigenous Australians and the populous Asian countries of the region [were] threatening, [and] racially-defined [as] others against whom the new white settlers defined their identity and interests. ${ }^{92}$

This too was reflected in multilateral attempts to root out dual nationality. Underpinning a range of international measures and processes, including The Hague Convention and The Report of the ILC on Multiple Nationality, was the presumption that holding multiple allegiances was undesirable and should be avoided. ${ }^{93}$

\footnotetext{
89 Arcioni and Rubenstein (n 45) 65.

90 Noa Bloch, The Case for a Non-Originalist Construction of Section 44(i) of the Constitution (Honours Thesis, Monash University 2018) 20-26.

91 Judith Brett, Australian Liberals and the Moral Middle Class: From Alfred Deakin to John Howard (Cambridge University Press 2003) 126.

92 Ibid 45.

93 Rubenstein (n 8); see Spiro (n 18).
} 


\section{READING DOWN SECTION 44(i) OF THE AUSTRALIAN CONSTITUTION AS A METHOD OF AFFIRMING AUSTRALIAN CITIZENSHIP}

However, at least by the 1960s, the White Australian policy was officially dismantled. Whilst it is disputed whether it was Holt or Whitlam who officially reversed the White Australia policy, the practical end was facilitated by the Fraser Government which made several multiculturalism achievements, ${ }^{94}$ including transforming the idea of multiculturalism into an immigration policy framework. ${ }^{95}$ Furthermore, by the 1990s, immigration was perceived as " "good" for everybody gastronomically, culturally and politically'. ${ }^{96}$ With 52 per cent of Australians 'in support of the current immigration level or in support of an increased intake, ${ }^{97}$ Australia is today considered one of the most receptive Western countries to immigration..$^{98}$

Therefore, the originalist application of section 44(i) applied in Re Canavan reflects Australians' pre-1960s fear of cultural diversity and dual allegiance. Instead, construction of section 44(i) should account for a broader analysis of multiculturalism and immigration history in Australia.

Second, similar to section 41, the democratic principles of popular sovereignty and representative government underpin section 44(i) and could inform its construction.

A body of case law has grown which affirms the constitutionally enshrined principle of representative government: ${ }^{99}$

That the Constitution intended to provide for the institutions of representative and responsible government is made clear both by the Convention Debates and by the terms of the Constitution itself. ${ }^{100}$

94 Brett attributes the policy shift to Whitlam, see Brett (n 88). The National Museum of Australia attributes the dismantling of White Australia to Holt. See National Museum of Australia, 'White Australia Policy Ends' <http://www.nma.gov.au/online_features/ defining_moments/featured/end_of_the_white_australia_policy $>$ accessed 20 November 2018. Markus argues that the policy shift was put into practice by Fraser and therefore attributes the policy shift to him, see Andrew Markus, Race: John Howard and the remaking of Australia (Allen \& Unwin 2001).

95 Brett (n 91).

96 Ibid 98.

97 Andrew Markus, 'Attitudes to Immigration and Cultural Diversity in Australia' (2014) 50(1) Journal of Sociology 10, 10.

98 Ibid.

99 Australian Capital Television (1992) 177 CLR 106; Nationwide News Pty Ltd v Wills [1992] 177 CLR 1; Lange v Australian Broadcasting Corporation [1997] 189 CLR 520. 100 Lange (1997) 189 CLR 520, 557. 
Sections 7 and 24 of the Constitution stipulate that members of the House of Representatives and Senate shall be directly chosen by the people at periodic elections. The requirement to 'effectuate the free election of representatives at periodic elections'101 was the basis of the Court's provision of representative government within the Constitution in Lange. The Court found that '[s]ections 1, $7,8,13,24,25,28$ and 30 of the Constitution give effect to the purpose of selfgovernment by providing for the fundamental features of representative government. ${ }^{\prime}{ }^{102}$

Courts have acknowledged popular sovereignty within the Constitution by recognising several modes of civic engagement as constitutionally protected. This includes the right to political communication, ${ }^{103}$ speech ${ }^{104}$ voting, ${ }^{105}$ political funding ${ }^{106}$ and access for political activity. ${ }^{107}$

Courts will give effect to the implied freedom to engage civically ${ }^{108}$ by recognising the protections necessary to ensure the political sovereignty of the people. ${ }^{109}$ This was illustrated in Roach when the Court struck down legislation which sought to extinguish prisoners' right to vote and their membership in the body politic.

Furthermore, Keane $\mathrm{J}$ argues that the Commonwealth enfranchisement of the people, as stipulated in sections 7 and 24, establishes 'that the people of the Commonwealth are the sovereign power'. ${ }^{110}$ Unlike the United States Constitution which protects the rights of the individual, the Constitution frames the freedoms of civic engagement and responsible government in 'collectivist and egalitarian'111 terms; it serves the aggregate interests of the Australian people by guaranteeing '[e]quality of opportunity to participate in the exercise of political sovereignty [which] is an aspect of the representative democracy'. ${ }^{12}$

If political unity is implicit within the principles of responsible government and popular sovereignty, any organ of government should be denied the power 'to

\footnotetext{
101 Ibid.

102 Ibid.

103 Ibid.

104 Levy v Victoria [1997] 189 CLR 579.

105 Roach (2007) 233 CLR 162; Rowe v Electoral Commissioner [2010] 243 CLR 1.

106 Unions NSWv New South Wales [2013] 252 CLR 530.

107 Attorney-General (SA) v Corporation of the City of Adelaide [2013] 249 CLR 1.

108 Unions [2013] 252 CLR 530.

109 Ibid.

110 Patrick Keane, 'The People and the Constitution' (2016) 42(3) Monash University Law Review 529, 538.

111 Ibid 539.

112 McCloy v New South Wales [2015] 257 CLR 178, 207 [45].
} 
divide or segregate the people in terms of religion, race, gender or social condition'. ${ }^{13}$ Yet, section 44(i) 'effectively create[s] two types of Australian citizens: those who can participate fully, and those who cannot'. ${ }^{14}$ The very premise of the section, which is to divide the population, is at odds with the implied constitutional freedoms the courts have recognised. ${ }^{115}$

In Re Canavan, the Court stressed that no disqualification under section 44(i) could undermine the constitutional principles of representative and responsible government. ${ }^{116}$ And yet, section 44(i) directly undermines the constitutionally enshrined principles of popular sovereignty and representative government. Therefore, applying the methodology of Murphy $\mathrm{J}$ and Rubenstein, the parties could have argued for an alternate construction of section 44(i) which is consistent with these constitutional principles.

\section{CONCLUSION}

Irrespective of whether one follows the methodology of the majority or minority decisions from Sipka, this article has explained how the Sipka judgments could have guided the Court to read down section 44(i) so that it was no longer operative. This would then have meant that the Parliament would have been responsible for drafting disqualification provisions, if it so desired, around dual citizenship, through the Electoral Act. This approach would have been democratically motivated; it would have enabled Parliament to determine legislatively what it means to be a full member of the Australian citizenship community, cognisant of developments in Australian citizenship law and multiculturalism. Furthermore, as this determination would be formulated by democratically elected representatives, it is more consistent with the constitutional principles of representative government and popular sovereignty.

113 Keane (n 110) 539.

114 Helen Irving, 'Citizens and Not-quite Citizens' (1993) 2(4) Constitutional Centenary: The Newsletter of the Constitutional Centenary Foundation 8, 10.

115 For the sake of completeness, it should be noted that other commentators have considered section 44(i) as undermining different democratic, constitutional freedoms (and not just representative government and popular sovereignty). Jeremy Kirk argued that it undermines the freedom to nominate for elections. See Jeremy Kirk, 'Constitutional Implications from Representative Democracy’ (1995) 23(1) FLR 37. Peter Bailey argued that it undermines the democratic right to be elected. See Peter Bailey, Human Rights: Australia in an International Context (Butterworths 1990). Helen Irving argued that it contradicts multiculturalism and undermines the principle of equality by creating two subclasses of citizens. See Irving (n 114).

116 See (n 35) and the accompanying text. 
In arguing this, we should note that in seeking to update the Electoral Act, the Parliament would also be restrained by the constitutional principles outlined in this article that could have lead to the reading down of section 44(i). For example, it would be at odds with popular sovereignty to include in the Electoral Act a section which automatically disqualifies a person with blue eyes. Yet, it would still be open to the Parliament to identify methods of identifying 'split allegiances' or including provisions in the Electoral Act for automatically disqualifying someone where a direct conflict arises between Australia and the country of their second citizenship, such as being a citizen of a country at war with Australia, with a requirement at that time for renunciation of that citizenship in order to continue to be a member of Parliament.

Finally, it is worth noting that the electorate's lack of concern over dual nationality was reinforced recently when all dual nationals forced to recontest their seats in the 2018 by-elections were returned. ${ }^{117}$ To some extent this also affirms how the Australian community has undergone a developmental process since 1901 and the concept of a single allegiance does not reflect Australians' life experiences. This does not mean that earlier cases, such as Sykes, were wrongly decided. Rather, the national understanding of membership has shifted; dual citizenship is no longer viewed as less attractive by the voting public, and this is consistent with the legislative changes around dual citizenship in Australia, suggesting that section 44(i) is no longer necessary. For those members of the public still fearful of a dual citizen who is standing for Parliament, they would continue to have the opportunity to choose not to vote for that person as their representative, which is a more democratic way of managing those concerns.

Fundamentally however, the changes in Australia's citizenship legislation, together with the actual changes in the composition of Australian society, were both avenues for the Court, to read down section 44(i) of the Constitution. This would have simply solved the constitutional hurdles that now continue to prevent Australia's dual citizens from exercising their active citizenship in the fullest sense of the word.

117 Stephen Donoghue, 'The Collision of History and Text: The Story of Dual Citizens and section 44(i) of the Constitution' (Speech delivered at the 2018 Melbourne University Law Students' Society Sir Anthony Mason Lecture, Melbourne, 1 August 2018). 